\title{
Social Capital and Entrepreneurship: Does the Relationship Hold in Deprived Urban Neighbourhoods?
}

Nick Williams

Centre for Enterprise and Entrepreneurship Studies, University of Leeds, Leeds, UK.

E-mail: n.e.williams@leeds.ac.uk

\section{Robert Huggins}

School of Planning and Geography, Cardiff University, Glamorgan Building, King Edward VII Avenue, Cardiff, CF10 3WA, UK

E-mail: HugginsR@cardiff.ac.uk

Tel: +44(0)2920876006

\section{Piers Thompson}

Nottingham Business School, Nottingham Trent University, $8^{\text {th }}$ Floor Newton Building, 50 Shakespeare Street, Nottingham, NG1 4FQ, UK

E-mail: piers.thompson@ntu.ac.uk

Tel: +44 (0) 1158482143

\section{ABSTRACT}

The aim of this paper to examine the relationship between social capital and entrepreneurship in deprived urban neighbourhoods. While there is a great deal of research on social capital, its usage and value in deprived areas is an under-researched topic. Drawing on survey data, it is found that social capital in the form of network ties within a DUN is linked to how entrepreneurship develops in these places. The breadth and variety of network ties that individuals are able to identify as sources of advice is related to the probability of considering an entrepreneurial career, and is even more strongly related to the conversion of entrepreneurial intentions into full engagement. If entrepreneurship is to be harnessed in DUNs a starting point is the enhancement of initiatives for developing social capital incorporating local businesses, residents and local government agencies.

Key words: Entrepreneurship, social capital, deprived urban neighbourhoods

Please cite this article as follows:

Williams, N. Huggins, R. and Thompson, P. (2017) 'Social Capital and Entrepreneurship: Does the Relationship Hold in Deprived Urban Neighbourhoods?', Growth and Change, doi: 10.1111/grow.12197

which has been published in final form at:

http://dx.doi.org/10.1111/grow.12197

This article may be used for non-commercial purposes in accordance with Wiley Terms and Conditions for Self-Archiving. 


\title{
Social Capital and Entrepreneurship: Does the Relationship Hold in Deprived Urban Neighbourhoods?
}

\begin{abstract}
The aim of this paper to examine the relationship between social capital and entrepreneurship in deprived urban neighbourhoods. While there is a great deal of research on social capital, its usage and value in deprived areas is an under-researched topic. Drawing on survey data, it is found that social capital in the form of network ties within a DUN is linked to how entrepreneurship develops in these places. The breadth and variety of network ties that individuals are able to identify as sources of advice is related to the probability of considering an entrepreneurial career, and is even more strongly related to the conversion of entrepreneurial intentions into full engagement. If entrepreneurship is to be harnessed in DUNs a starting point is the enhancement of initiatives for developing social capital incorporating local businesses, residents and local government agencies.
\end{abstract}

Key words: Entrepreneurship, social capital, deprived urban neighbourhoods

\section{INTRODUCTION}

Social capital plays a key role in how and where entrepreneurship develops (Coleman, 1990, 2000; Putnam, 1995; Evans and Syrett, 2007; Malecki, 2012; Western et al, 2005; Westlund et al, 2014). Social capital has emerged as one of the most researched theories in the social sciences and can be defined as access to resources derived from diverse network engagement and normative behaviour (Coleman, 1990; Putnam, 2000; Lee et al, 2007; Parra-Requena et al, 2010), which can be built up through formal networks as well as informal channels, the relative strengths of which will depend on the dynamics of place (Western et al, 2005) and perceptions of place (Sleutjes and Schutjens, 2013). Indeed, entrepreneurship is not solely based on formalised contracts and alliances but is inherently a socialised process based on informal social networks that provide valuable resources (Lee et al, 2011). The social network approach to examining entrepreneurship is largely based on Granovetter's (1973) definition of strong and weak ties. Strong ties are defined as network relationship characterised by frequent interactions, a long duration of association, and a close emotional bond; whereas weak ties are defined as network relationships characterised by infrequent 
interactions, a short duration of association, and a lack of a close emotional bond, and are typically newer network ties (Jack, 2005). In starting and growing a business, the number and strength of ties within the founder's network can be critical (Kreiser et al., 2013).

Although social capital in more affluent and successful localities is largely understood and well-researched (Middleton et al., 2005), the nature and extent of local social capital resources in deprived urban neighbourhoods (DUNs) remains under-researched (Lee et al, 2011). As such, this paper explores social capital in the form of the nature of network ties and their impact on entrepreneurs in a DUN. Drawing on data from a survey of residents in a DUN, it contributes to an improved theoretical understanding of how place moderates the association between entrepreneurship and social capital. At the outset it is important to define what we mean by entrepreneurship. Although it is often defined as the foundation of new businesses, the concept is increasingly being defined and applied in several contexts (Westlund, 2011; Westlund et al, 2014). However, for the purposes of this study we limit ourselves to analysing entrepreneurship in the form of start-ups.

In the next section, the literature on entrepreneurship and social capital is examined, particularly focusing on DUNs. A summary of the methodological parameters employed for the data collection and analysis is followed by a presentation of the results. Finally, the paper then reflects on the findings and provides conclusions from the context of future policy development.

\section{ENTREPRENEURSHIP, SOCIAL CAPITAL AND DUNs}

Within even relatively prosperous cities, concentrations of poverty and social inequality are persistent (Broadway et al, 1989; Syrett and Sepulveda, 2012). In addition, DUNs are often characterised by low levels of entrepreneurship. Support for entrepreneurship is a core aspect of economic development strategies (Clifton et al, 2010; Stephens and Partridge, 2011), and 
policy makers often seduced by the desire to harness the 'entrepreneurial pixie dust that makes some cities sparkle with success, as others rust under the weight of excessive regulation' (Peck, 2016: 18). Similarly, policy has focused efforts on DUNs, with entrepreneurship viewed as a method of improving economic outcomes and combating social exclusion (Williams and Williams, 2011; Sleutjes et al, 2012). Yet reversing historically low levels of entrepreneurship in deprived urban environments brings significant challenges. In the UK the rate of business start-ups in the 20 most deprived local authority areas in the UK being half the rate in the 20 most prosperous (Williams and Williams, 2011). Such differences may be explained by the presence of numerous barriers to entrepreneurship, including residents lacking the necessary business skills, a lack of appropriate access to finance, an absence of mentoring and advice, and a lack of role models (Slack, 2005; Rouse and Jayarwana, 2006; Welter et al., 2008). While such barriers are not exclusively faced by entrepreneurs in DUNs, they are likely to be more acute than in more affluent areas (Welter et al., 2008).

Social capital is commonly associated with the assets required to achieve or maintain an individual's or group's position within social structures and networks, through actions governed by social norms, rules and interactions (Bourdieu, 1986; Coleman, 1988). In terms of understanding the different forms such social capital may take it as necessary to delve further into the myriad of definitions that have been employed to identify and explain the phenomena that can be considered to constitute social capital (Sobel, 2002). For instance, Ostrom and Ahn (2003: 1) consider social capital as 'an attribute of individuals and of their relationships that enhance their ability to solve collective problems'. Coleman (1988: 98) concurs with this view stating that social capital exists in the 'relations among actors'. Similarly, other authors such as Conway and Steward (2009) consider social capital to be located in 'relationships'. Dasgupta (2003) views social capital as a 'system of interpersonal 
networks' and 'nothing more', and develops this statement by referring to a prerequisite for social capital as being the maintenance of trust that members of an interpersonal network have in each other. This maintenance is achieved by the 'mutual enforcement of agreements'. Developing the notion of agreement, Fountain (1998) considers efficient and effective networks to have the capability to resolve conflict. Dasgupta (2005), on the other hand, considers the quality of an interpersonal network to be dependent upon the use to which it is put. Others, like Fukuyama (2003: 1), define social capital as 'an instantiated informal norm that promotes cooperation'. Social capital is described by Coleman (1988) as not being a unitary entity, rather a number of different entities. Dasgupta (2003) also refers to the variety of forms of social capital. Similarly, Beugelsdijk and Van Schaik (2005) and Woolcock and Narayan (2000) allude to the multidimensional nature of social capital.

Despite the numerous barriers faced, the development of social capital has the potential to empower people to become entrepreneurial (Westlund and Bolton, 2003; Acs and Kallas, 2007; Thompson et al., 2012). Trust can be built in a local neighbourhood through familiarity resulting from past experiences, repeated transactions and face-to-face contacts, and can be particularly important in deprived areas (Welter et al., 2008). However, deprived areas are often considered to lack effective social capital (Middleton et al., 2005; Slack, 2005; Welter et al., 2008) or the capacity to benefit from it where it does exist (Evans et al., 2006).

Affluent localities are often considered to contain high quality human capital, adequate financial capital and social capital and can therefore more readily take advantage of entrepreneurial opportunities (Acs and Kallas, 2007; Thompson et al., 2012). Similarly, entrepreneurs from higher socio-economic groupings are more likely to have individuals within their social network that are familiar with the business environment who can influence them (Anderson and Miller, 2003). However, in DUNs these factors are more often than not absent (Acs and Kallas, 2007), with a lack of social capital impacting on individuals' ability 
to spot and take advantage of entrepreneurial opportunities (Lee et al, 2011) and can also discourage entrepreneurs from investing locally (Sleutjes and Schutjens, 2013). Residents in low-income neighbourhoods may be deeply embedded in networks of mutual support, providing free services for one another ranging from car repair to hairstyling, but these networks do not necessarily translate into a resource that can in turn be leveraged for economic benefit (Hays and Kogl, 2007). As social capital, in the form of the network ties present, is linked to the ability to exploit information (Okoli and Oh, 2007) and a large diverse network can enhance entrepreneurial success (Ma, 2002; Lee et al, 2007). The literature highlights that social capital is an important dimension in building capacity for entrepreneurship (Westlund and Bolton, 2003; Welter et al., 2008; Lee et al, 2011). Furthermore, social capital is a spatial characteristic and resource endowment (Westlund and Bolton, 2003), and therefore 'place' is critical in understanding how entrepreneurial opportunities emerge and are exploited as 'local circumstances are the only meaningful point of departure' (Morgan, 2004, p. 18).

\section{METHODS}

\section{Study Area}

The research was conducted in the northern English city of Leeds in the 31 Super Output Areas (SOAs) within the city which feature in the most poorly performing $3 \%$ of SOAs nationally (Leeds City Council, 2011). SOAs are geographically designed for the collection and publication of small area statistics (Higgins et al, 2012). The most deprived SOAs are calculated using seven 'domains of deprivation' which are: (1) income deprivation; (2) employment deprivation; (3) health deprivation and disability; (4) education, skills and training deprivation; (5) barriers to housing and services; (6) living environment deprivation; and (7) crime (DCLG, 2007). The domains are designed to measure the major features of 
deprivation, and not simply conditions experienced by a small number of people or areas (DCLG, 2007).

Leeds is the largest centre of economic activity in the Yorkshire and Humber region and is the second largest metropolitan district in England with a population of over 700,000 people (Leeds City Council, 2011, 2012). The city has enjoyed strong growth in the last two decades, yet areas of deprivation are persistent with examples of poverty and prosperity seen in close proximity (Leeds City Council, 2012). The SOAs covered by the survey consist of the neighbourhoods of Burmantofts, Chapeltown, Fairfield, Gipton, Harehills, Little London, Richmond Hill, Seacroft and South Leeds in the city of Leeds. These areas have high levels of unemployment which are more than double the city's average, as well as exhibiting stark inequalities in educational achievement, house prices, health and crime. Unsurprisingly, levels of business start-ups are also low, and the contribution of smaller firms to job creation within the poorer areas is below the average for the Leeds district and the region (Williams and Williams, 2011, 2012).

\section{Data}

The methodology underpinning the primary data collection and analysis consists of a quantitative survey of entrepreneurs and potential entrepreneurs in the study area. The data collection analysis process for each is described below.

Survey Data Collection - For the quantitative survey, a spatially stratified sampling technique was employed to select households within the study area for interview (Kitchen and Tate, 2001). If there were some 1000 households in an area, then the researcher called at every $10^{\text {th }}$ household. If there was no response and/or an interview was refused, then the 11th household was visited, then the 9 th, 12 th, 8 th and so on. This provided a spatially stratified sample of 
each district. A total of 442 face-to-face surveys were completed. To generate an appropriate sample, profile data including gender, age, ethnicity; educational attainment, employment status and income, was analysed for the Leeds LEGI area. From this, a sample was devised which represented the entire population and which will enable conclusions to be drawn. Table A1 compares the sample with the census statistics available for the areas in terms of the key characteristics controlled for in this study. The data indicates that through the completion of 442 interviews, the data is representative at the $95 \%$ confidence interval for gender, ethnicity and educational attainment, which is suitable for this type of research (Bryman and Cramer 2001). Where the sample does deviate from the underlying population is in terms of its age distribution. The prime age group ( 25 to 44 years) is over-represented whilst the younger age groups are under-represented. This should be borne in mind when interpreting the descriptive results as those in the younger age group may be less likely to be ready to engage in entrepreneurial activities and will have differing social capital available to them. However, as discussed below we control for age using a multiple regression analysis approach, which should account for such differences. These surveys provide information relating to entrepreneurial activity and intentions examined as well as the sources of help, advice and support that residents of deprived areas would look to if they were to start a business. The survey also provides information on a variety of other characteristics that past studies suggest will also influence the decision to start a business. The entrepreneurial, social capital and other influential variables utilised in the analysis are outlined in more detail below. In order to accommodate the other factors that may determine entrepreneurial activity and interest, a binary logistic regression approach is adopted.

\section{Measuring Entrepreneurial Engagement and Interest}


Given that previous studies have found that actual entrepreneurial activity in more deprived areas of the UK is relatively low (Thompson et al., 2012; Williams and Williams, 2012), restricting the analysis to those actively engaged in entrepreneurship may not give a true indication of the extent that entrepreneurship is accepted in such communities. Survey participants, therefore, were asked to select which of the following statements relating to entrepreneurship and business ownership applied to them: (1) I expect to start a business in the next three years; (2) I know an entrepreneur/someone who is self-employed; (3) There are good start-up opportunities where I live; (4) I have the skills to start a business; (5) I run a business; (6) I am in the process of starting a business; (7) None of these. As such, the survey utilises two main measures of entrepreneurial activity and entrepreneurial intentions/consideration. The first corresponds to those fully engaging in entrepreneurial activity, and captures those initiating new entrepreneurial ventures, as well as those currently running existing businesses. Such entrepreneurially active individuals are relatively rare in the study area with only 35 in the total sample of 442 .

The second measure excludes those currently involved in entrepreneurial activities, but instead captures those displaying positive entrepreneurial intentions for future or current involvement. In this case, the number of respondents expecting to start a business in the near future is low $(N=21)$. In order to better capture all of those who have an interest in starting a business, even if they do not expect to in the near future, we also include those who although stating that they were not intending to start a business did indicate that they had considered starting their own business or becoming self-employed. This was captured through a second item asked of those who did not indicate they were starting or running a business currently. This second measure, therefore, includes those intending to start a business within the next three years and those that have considered it as a potential career choice in the past or present, resulting in a subgroup of 102 respondents. Those who are active entrepreneurs are not 
included in the analysis when examining the relationship between network ties and consideration of an entrepreneurial career. As discussed below we also control for household income when analysing those intending/considering starting a business where data is missing, which leaves a total of 329 respondents.

\section{Network Ties and Social Capital}

In order to capture social capital, both in terms of the extent and variety of ties that are possessed, respondents were also asked to identify those they would seek advice from if they were to start a business. To capture this, the following item was used: (1) For those already starting or running a business - Where did you go for help/advice/support when setting up your business?; (2) For those who have not already started businesses - If you were to start-up your own business, where would you go for help/advice/support?

No prompting was used to try to ascertain the variety of potential sources of advice and support that individuals are aware of. The variable included in the regression analysis is a count of the different types of sources of advice and support that are identified. The expectation here is that the greater the variety of sources identified, the wider the variety of knowledge, information and resources that this will provide access to (Greve and Salaff, 2003), the more valuable the social capital held. This would tend to mean that even where some ties do limit entrepreneurial ambition other ties will overcome this.

We also consider the variety of ties identified as sources of advice, which are split into two categories: strong and weak ties. Strong ties associated with bonding ties include family, friends and work colleagues, while weak ties include all other groups or individuals identified by the respondents. This division is imperfect in that the nature of the relationship is not directly captured, but the first group of strong ties is likely to provide access to similar information as that held by the respondent. Those classed as weak ties are generally reflective 
of more professional relationships such as with banks that even where based in the same local area will provide access to a broader array of information and potential network ties. Table 1 below shows that for just under half the sample no possible sources of advice could be identified, with only 4.9 percent able to identify three or more sources. This means that on average only 0.738 ties were identified by each respondent. Interestingly, no strong ties were identified by 72.6 per cent, whilst 66 per cent of the sample could not identify any less proximate sources of support and advice through weak ties.

\section{Table 1 About Here}

Survey Data Analysis - In order to control for the personal characteristics that are likely to influence the decision to start a new enterprise a multivariate approach is adopted. As the dependent variables of entrepreneurial engagement and consideration of an entrepreneurial career take a discrete form, binary logistic regressions are utilised to identify those characteristics associated with positive attitudes towards entrepreneurship. Those factors influencing the probability of considering an entrepreneurial career choice are likely to fall into a number of groups, the personal characteristics of the individual, cultural influence of the area, and the extent and nature of the respondent's network. The logit regression itself takes the form of the natural log of the odds of the estimated probability of the individual having considered an entrepreneurial career $(\hat{p})$. This means that the regressions will take the following general form:

$$
\ln \left(\frac{\hat{p}}{1-\hat{p}}\right)=\alpha+\text { Personal }_{i}+\text { גArea }_{i}+\lambda \text { Network }_{i}
$$


where Personal is a vector of individual characteristics, which have been found to influence entrepreneurial intentions and activity in prior work. Area represents controls for the area within which the individual lives, allowing for the possibility of cultural differences between the areas from which the sample is drawn. The vector Network contains those variables representing the social capital-based network ties that individuals are able to identify as possible sources of information when starting a new business. The estimated coefficients are reported in the results tables. Where appropriate the odds-ratios representing the increase in likelihood of being entrepreneurially active associated with a particular are also discussed in the text. As entrepreneurial activity is relatively uncommon in DUNs we also ran rare events logits to correct for any bias introduced into the results due to the standard logits underestimating the rare outcome, engagement with entrepreneurial activity (King and Zeng, 2001a; 2001b). As the significant results generated were identical these have not been reported in the following section, but are available from the authors on request.

\section{Personal Characteristics Associated with Entrepreneurship}

The personal characteristics included in the regressions are those that have been found to be associated with either entrepreneurial intentions or activity within past studies (see Table A2 in the appendix for the distribution of these variables). Past studies have found that men are significantly more likely to display an interest or actively engage with entrepreneurship than their female counterparts after controlling for other characteristics (Brush, 1992). There is less agreement as to why women are less inclined towards an entrepreneurial career with greater risk aversion (Caliendo et al., 2009), perceptions or actual limited access to finance (Carter et al., 2015), and differing roles in families and society (Mueller and Conway DatoOn, 2013) suggested by different studies. 
An inverted U-shaped relationship between age and entrepreneurship is suggested to exist because of opposing forces associated with needing to acquire relevant experience and requiring sufficient time to obtain a return on the time, money and effort invested (Kim, 2007). In order to allow for this, a categorical age variable is used to allow for a non-linear relationship. As with other independent variables dummies are therefore included to represent particular groups in the sample, comparing them to an omitted base category (see Table A1). There is also suggested to be a positive relationship between more formal human capital in the shape of higher educational attainment and entrepreneurship due to greater skills for opportunity recognition (Robson and Sexton, 1994; Block et al., 2011). However, those with the highest educational qualifications also have the best alternative employment opportunities, raising the opportunity cost of entrepreneurial careers (Van der Sluis et al., 2008). In DUNs, finding employment may be particularly hard if there is any stigma effect (Atkinson and Kintrea, 2001), which may push those with lower qualifications into business ownership. In a similar fashion to the age variable, dummies are included for those with educational qualifications at either end of the spectrum.

A lack of access to finance is suggested to be a considerable barrier to entrepreneurial activity in general (Williams and Williams, 2011). In DUNs this could be even greater if a lack of familiarity means that mainstream lenders are unwilling to finance new businesses in these neighbourhoods (HM Treasury, 2005). This may personal wealth and income play an increased role. To capture this we include household income in the regressions of considering an entrepreneurial career. We do not include it in the entrepreneurial activity regressions as there is a strong possibility that any relationship will reflect income from the business rather than income being a cause of entrepreneurial activity.

Studies have also found considerable differences in entrepreneurial activity and intentions between differing ethnic groups (Ram et al., 2006). This can be due to both 
negative influences such as discrimination in the mainstream labour market and positive pull factors associated with access to ethnic resources such as low cost labour and alternative sources of finance (Ram et al., 2000; Levent et al., 2003). The subsamples for most ethnic minority groups are too small to utilise in the analysis to isolate differences found by previous studies (Thompson et al., 2010; Clark and Drinkwater, 2010). However, while imperfect, a dummy is used to represent those that are non-white to capture this potential influence.

\section{Area Characteristics}

We also endeavour to capture those cultural influences from the area and community itself. Studies have suggested that starting and running enterprises in more DUNs may be hindered where less finance is available (Williams and Williams, 2011) and low incomes reduce demand for output (Storey and Johnson, 1987). Some studies suggest that these barriers are often perceived to be greater than they actually are, so for example after controlling for other characteristics finance may be no harder to acquire in DUNs than elsewhere (Lee and Drever, 2014). In this case, dummies are included to represent the five areas covered by the study. We also try to capture the attachment to the area that individuals feel, as other studies have suggested that entrepreneurial activity may be associated with a greater propensity to leave an area (Frankish et al., 2015; Thompson et al., 2012). However, it is also possible that those more strongly embedded in the area will be better able to leverage the resources available within this local area (Atkinson and Kintrea, 2001). This is captured by the following item: 'How likely is it that you (and your household) will move to a different home in the next 5 years?' This was rated on a five point scale with the following categories: very likely, likely, unsure, unlikely, and very unlikely. Dummies were included to capture those indicating that 
they were either likely or very likely to move, and those either unlikely or very unlikely to move.

Recognising that not all social capital is necessarily a positive influence on entrepreneurial activity and intentions, we control for those who answer negatively when asked 'Do you think (Your Local Area) is a good place to start a business?' We also consider whether the perception of the local areas influences the relationship between network ties and entrepreneurial activities and consideration. This is captured by including interaction terms for the perception that an areas is not suited for business starts with the social capital network variables. In effect, where areas are perceived to be poorly suited for business starts it might be expected that strong bonding ties are more likely to act as drag chains, and have limited influence in encouraging engagement with entrepreneurship, as well as being insular or even negative in nature due to their association with non-productive activities (Evans et al., 2006; Middleton et al., 2005; Hogget, 1997; Portes and Landolt, 1996) Although, network ties may be present, they may not provide access to valuable knowledge and resources (Hays and Kogl, 2007; Gedajlovic et al., 2013). Furthermore, potentially weaker ties to sources of advice and support outside the area may be more effective in accessing new resources and overcoming the barriers to entrepreneurship experienced (Sullivan and Ford, 2014). As such, it may be expected that a positive interaction effect will be present for weak ties and areas perceived to be poor for business starts, whilst a negative interaction might be expected for strong ties in such areas.

\section{RESULTS}

Table 2 presents the proportion of respondents identifying each of the individual sources of advice. As well as the sample as a whole, the proportion of active entrepreneurs is also compared to the percentage of non-entrepreneurs who note a source (Panel A). Panel B 
provides a similar division, but based on those considering an entrepreneurial career and those who have not. The most commonly named source of advice was friends and family, with nearly a quarter of respondents indicating that they would seek advice from this source (24.2 percent), with 18.8 percent naming banks and other financial institutions are the second most popular source. The small number of respondents engaging in entrepreneurial careers makes it impossible to statistically compare the use of individual ties between entrepreneurs and non-entrepreneurs. Comparing those considering and not considering entrepreneurial careers, one type of tie displays a weakly significant difference, work colleagues are identified as a potential source of advice more heavily by those considering an entrepreneurial career.

Table 2 About Here

The mean number of different sources of advice sought is slightly higher for those who have engaged with an entrepreneurial career (1.00 ties) compared to those have not pursued entrepreneurship actively (0.72 ties). This difference is significant, but relatively weakly ( $\mathrm{t}$ value $=1.877, \mathrm{p}$-value $=0.061)$. The gap is smaller when comparing those who have merely considered an entrepreneurial career rather than actively engaged in one (1.06 ties) with those who have not considered an entrepreneurial career at all (0.90 ties) and not significantly different $(\mathrm{t}$-value $=1.295, \mathrm{p}$-value $=0.197)$. These results indicate that social capital has less bearing on the earlier stages of entrepreneurship in terms of developing an interest and ambition in starting a business, but appear to have a stronger role to play in moving any entrepreneurial intentions to fruition. This is not necessarily inconsistent with those studies that have suggested that a lack of role models is a primary explanation for low levels of entrepreneurial engagement in deprived areas (Van Den Berg et al., 2004), but perhaps 
suggest that the key influence of these role models in DUNs currently comes at a later stage than is suggested by some (Van Auken et al., 2006).

As a majority of the measures captured in the survey are categorical in nature, Table 3 reports the Spearman rank correlation coefficients rather than Pearson correlation coefficients.

\section{Table 3 About Here}

The correlations in Table 3 confirm the weak relationship between the number of different network ties identified by a respondent and entrepreneurial activity. No such relationship exists for those simply considering entrepreneurship, but not actively engaging in it. Positive correlations are found between both measures and gender, with males more likely to be engaged in or considering entrepreneurial activity as found in prior studies (Bonte and Piegeler, 2013). Interestingly, there is some evidence that those with higher qualifications in DUNs are less likely to become entrepreneurs, perhaps reflecting the alternatives available to them (Van Der Sluis et al., 2008). From the results presented here, it is possible to argue that entrepreneurship as envisaged by Frankish et al. (2015) and Thompson et al. (2012) is seen as a potential method of escaping DUNs, as those intending to move are more likely to have considered an entrepreneurial career. However, for those who actually engage in such entrepreneurial activities there is no relationship with the probability of moving in the next five years. The correlation coefficients between the independent variables indicate that multicollinearity will not be a problem, with no coefficients greater than 0.150 . Even the number of weak and strong network ties are not found to be significantly related $(\rho=0.046$, p-value $=$ $0.333)$.

Table 4 presents the logit regression results concerning those individuals starting or running businesses at the point of their interviews. The likelihood ratio (LR) tests indicate that the null of constant probability can be rejected for the models including network ties. The 
Hosmer-Lemeshow tests also suggest that the null of a good fit to the data cannot be rejected. This is also the case for the regressions relating to consideration of an entrepreneurial career. Although the regressions correctly predict the entrepreneurial activity of 92.1 percent of the respondents, this is to a large extent reflective of the relative scarcity of entrepreneurially active individuals. Only 9 percent of the deviation $\left(R^{2}=0.090\right)$ is explained according to the pseudo $R^{2}$ values when no social capital variables are included (Model 0a). This rises to 11 percent when allowing for the social capital, as represented by the variety of network ties identified by respondents, to be interacted with perceptions about the local area's suitability for start-up activity. Adding the social capital variables to the regressions significantly improves the estimations according to the LR-tests comparing Model 1a with Model 0a. This is confirmed by the AIC being smallest for Model 1a. The interaction term does not appear to improve the model.

\section{Table 4 About Here}

There is an apparent link between social capital, represented by the variety of network ties identified by respondents, and the probability of being entrepreneurially active, which remains significant at the 5 percent level when controlling for other personal characteristics (Model 1a). There is also weak evidence for positive perceptions of an area for business starts being linked to entrepreneurial activity. For entrepreneurial activity there is no evidence that perceptions of the area play a role either directly or through interacting with the network tie variable.

There is clearly a strong gender influence present with men significantly more likely to be currently involved in entrepreneurial careers. In fact, the odds ratio from Model 1a suggests that men are over three times as likely to be starting or running businesses than women in DUNs (odds ratio 3.286). Compared to the prime age group (25 to 44 years), the youngest (16 to 19 years) and oldest (45 to 59 years) members of the sample display weak 
evidence of being less likely to be entrepreneurially active, reflecting the findings of previous studies indicating the need to acquire sufficient experience, but also have sufficient time to recoup investments (Kim, 2007). With regard to human capital, as captured by more formal education and training, the results here are opposed to previous studies examining the general population of developed countries, which suggest a positive relationship between education and entrepreneurial activity (Davidsson and Honig, 2003; Block et al., 2011). In the DUN sample investigated here, those with no formal qualifications are more than two and half times (odds ratio $=2.631$, Model $1 \mathrm{a}$ ) as likely to be entrepreneurs as those with NVQ level 1 or 2 qualifications.

The dummy representing non-white respondents is positive, but is not significantly different from zero. In this case, some of the more subtle differences between ethnic groups might be lost through the aggregation into a single dummy variable as necessitated by subsample size. Finally there is no significant evidence that geographical location, or attachment to it, influence the probability of engagement with entrepreneurial careers, which is contrary to the suggestions of some studies such as Thompson et al. (2012) and Frankish et al. (2015). This might be explained by established entrepreneurs having already moved if this was their desire.

Although the results above are of value in indicating the importance of social capital in encouraging and instigating active engagement with entrepreneurial activity, given the limited presence of such activity in DUNs it would also be of value to understand whether social capital encourages more of the inhabitants of such neighbourhoods to contemplate an entrepreneurial career even if other barriers prevent such actions being acted upon (Slack, 2005). Table 5 presents the logit regressions when using the variable capturing all of those intending or having considered starting a business as the dependent variable. The percentage 
of deviation explained by the regressions is lower than that for entrepreneurial activity with 8 to 10 percent explained according to the pseudo $R^{2}$ values.

\section{Table 5 About Here}

Confirming the earlier findings that the social capital as captured by network ties has less effect on the initial stages of generating entrepreneurial intentions than the realisation of these there is found to be no direct link from the variety of ties accessed to consideration of an entrepreneurial career. Perceptions that the area is a poor place to start a business have no direct effect on consideration of an entrepreneurial career. However, Sullivan and Ford (2014) social capital plays a strong role in overcoming such concerns, with the interaction term between network ties and poor area for a business start positive and significant.

The other relationships found for entrepreneurial activity (Table 4) are also weakened or not evident for the consideration of an entrepreneurial career variable (Table 5). Men are more likely to have considered such a career, but the odds ratio in Model $1 \mathrm{~b}$ indicates that they are around twice as likely as their female counterparts to have undertaken such a consideration (odds ratio $=2.166$ ), rather than the much stronger relationship found for entrepreneurial activity previously.

Studies have suggested the type of network tie will have an important influence on the nature of social capital (Granovetter, 1973; Bruderl and Preisendorfer, 1998), which may influence the degree to which it will be of benefit for prospective entrepreneurs (Kreiser et al., 2013). Tables 6 and 7 below present the results when the social capital variables are split into strong and weak network ties for logit regressions of entrepreneurial activity and consideration of entrepreneurial careers respectively. In terms of entrepreneurial activity, the LR-tests indicate that the social capital variables have only a weakly significant influence on the likelihood of being currently engaged in such activities.

Table 6 About Here 
Whilst positive coefficients are estimated for both strong and weak network ties, but only that for weak network ties is significant. It therefore appears that in DUNs weak ties role in providing access to relevant knowledge (Sullivan and Ford, 2014) is more important than the emotional and financial support of strong ties (Sequerira et al., 2007). When interaction terms are included none of the coefficients accounting for the social capital from network ties are significant.

The results in Table 7 Model $3 \mathrm{~b}$ indicate that consideration of an entrepreneurial career is not significantly related to strong or weak network ties in DUNs. This is contrary to Sequeira et al. (2007) who found strong ties to boost entrepreneurial intentions, but this was when accompanied by high entrepreneurial self-efficacy. However, when interaction terms with the perception that an area is poorly suited for business starts are included weak ties in such areas are found to have a positive and significant effect on consideration of an entrepreneurial career.

\section{Table 7 About Here}

It appears that consideration of an entrepreneurial career is only related to the variety of ties available to an individual in areas perceived to be unsuitable for new business starts. It appears that weak network ties in particular can play a key role in overcoming the environmental restrictions on entrepreneurial intentions. When it comes to encouraging individuals to turn interest into activity regardless of perceptions of the area social capital from a wide variety of network ties makes entrepreneurial engagement more likely (Sequeira et al., 2007). Kreiser et al. (2012) found some evidence that the variety of weak, rather strong, ties increases the likelihood of entrepreneurial intentions becoming reality, which appears to be the case here. However, in DUNs the strongest relationship is found with the combined measure of social capital, which perhaps reflects the limited access to resources held by the individuals in DUNs, making strong ties more important than in the population as a whole. 


\section{DISCUSSION AND CONCLUSION}

Although much is known about the interaction between social capital and entrepreneurship in successful, entrepreneurial localities, less is known about the relationship in deprived areas with low levels of entrepreneurship. This paper contributes to research by examining the association between social capital and entrepreneurship in a DUN. The findings illustrate that social capital in the form of available network ties to individuals in a particular place is linked to how entrepreneurship develops in these places, in this case a DUN. It is found that the breadth and variety of sources of advice that individuals can identify is not significantly related to the probability of considering an entrepreneurial career in general. It does, however, play an important role in overcoming concerns about the suitability of a location in a DUN. It is also related to the conversion of any entrepreneurial intentions into full engagement.

The relatively poor quality of social capital in deprived areas seems to indicate that the breadth of networks has less influence on driving an initial interest in entrepreneurial careers. When faced by adverse economic conditions, such as those experienced in deprived areas, the individual motivation of latent entrepreneurs appears to be fundamental in sparking the process of investigating an entrepreneurial career. Social capital, then, contributes more strongly in turning this latent interest into full engagement.

It is notable that variables such as education, which are often associated with entrepreneurial career choices in studies using similarly sized samples of those better positioned within the labour force, are not positive influences here (Fraser et al., 2006). More work would clearly be required to confirm this, but it does suggest that career choices in general within more deprived areas are less likely to be planned in the same manner as those in more developed localities as a whole. This means that circumstantial events and 
serendipitous opportunities are likely to play a stronger role in both mainstream and entrepreneurial career choices. Potentially, therefore, the isolation of unemployed residents of such areas from the labour force, as a whole, is holding back their ability to undertake those longer-term activities, which would allow them to re-enter the workforce. Equally those with employment may not be planning for the next stages of their careers in a similar manner to those in other areas.

From a policy perspective, if entrepreneurship is to be harnessed in DUNs, a starting point may be the enhancement of initiatives for developing social capital incorporating local businesses, residents and local government agencies (Miles and Tully, 2007; Huggins and Williams, 2009; Lee et al., 2011). Bridging forms of social capital can be developed by giving support to community groups, while bonding forms can help to support the interests of the local business community (Welter et al., 2008; Williams and Williams, 2011). Although entrepreneurial activities will clearly not be a magic bullet that can solve all problems of deprived areas (Blackburn and Ram, 2006; Huggins and Williams, 2011), there could be significant benefits for the local economy from such activities. In order to encourage individuals in more deprived areas to seriously consider such careers there seems to be a need to make individuals aware of where advice might be sought and help provided to develop these relationships. Also, the use of community entrepreneurs who act as role models can be important (Malecki, 2012) and there are able to promote enterprising capabilities through the education system which may have the long-term potential to positively impact on residents' attitudes, including young people. While this has occurred as part of policy in other deprived areas it has often failed as role models have been implanted from outside the locality (Williams and Williams 2011). Instead, policy should focus on role models from the local community which entrepreneurs can be more influenced by rather nationally-renowned entrepreneurs from outside (Hindle and Klyver, 2007). 


\section{REFERENCES}

Acs Z.J. and Kallas K. (2007) State of literature on small to medium-size enterprises and entrepreneurship in low income communities. Max Planck Institute Discussion Papers on Entrepreneurship, Growth and Public Policy, 0307.

Anderson A.R. and Miller, C. (2003) Class matters: human and social capital in the entrepreneurial process. Journal of Socio-Economics, 32 17-36.

Atkinson, R. and Kintrea, K. (2001) Disentangling Area Effects: Evidence from Deprived and Non-deprived Neighbourhoods. Urban Studies 38 2277-2298

Beugelsdijk S and T. Van Schaik (2005) Differences in social capital between 54 Western European regions. Regional Studies 39(8): 1053-1064

Blackburn, R.A. and Ram, M. (2006) Fix or fixation? The contributions and limitations of entrepreneurship and small firms to combating social exclusion. Entrepreneurship and Regional Development 18 73-89

Block, J.H. Hoogerhide, L. and Thurik, R. (2011) Education and entrepreneurial choice: an instrumental variables analysis. International Small Business Journal 31(1), 23-33.

Bonte, W. and Piegeler, M. (2013) Gender gap in latent and nascent entrepreneurship: driven by competitiveness. Small Business Economics 41(4), 961-987.

Borgatti, S.P. and Foster P.C. (2003) The network paradigm in organizational research: a review and typology. Journal of Management 29 991-1013

Bourdieu, P. (1986) The forms of capital, in Richardson J. G. (Ed.) Handbook of Theory and Research for the Sociology of Education, pp. 241-258. Greenwood, New York, NY

Broadway, M.J., and Snyder, S.D. (1989) The persistence of urban deprivation: The example of Wichita, Kansas, in the 1970s. Growth and Change, 20(2), 50-61.

Brush, C.G. (1992) Research on women business owners: past trends, a new perspective and future directions. Entrepreneurship Theory and Practice 16(4) 5-30

Bryman, A. and Cramer, D. (2001) Quantitative Data Analysis with SPSS for Windows: A Guide for Social Scientists. Routledge, London.

Caliendo, M. Fossen, F.M. and Kritikos, A.S. (2009) Risk attitudes of nascent entrepreneursnew evidence from an experimentally validated survey. Small Business Economics 32(2) 153-167

Carter, S., Mwaura, S., Ram, M., Trehan, K. and Jones, T. (2015) Barriers to ethnic minority and women's enterprise: existing evidence, policy tensions and unsettled questions. International Small Business Journal 33(1) 49-69

Clark, K. and Drinkwater, S. (2010) Recent trends in minority ethnic entrepreneurship in Britain. International Small Business Journal 28(2) 136-146.

Clifton, N., Keast, R., Pickernell, D. and Senior, M. (2010) Network structure, knowledge governance and firm performance: Evidence from innovation networks and SMEs in the UK. Growth and Change, 41(3), 337-373.

Coleman JS (1988) Social capital in the creation of human capital. American Journal of Sociology. Supplement: Organizations and Institutions: Sociological and Economic Approaches to the Analysis of Social Structure 94 (Supplement): S95-S120.

Coleman, J.S. (1990) Foundations of Social Theory (Harvard University Press, Cambridge, MA)

Coleman, J.S. (2000) Social Capital in the Creation of Human Capital, in: Social Capital: A Multifaceted Perspective Eds P. Dasgupta and I, Serageldin 13-39, (World Bank, Washington, DC) 
Conway S and F. Steward (2009) Managing and Shaping Innovation. Oxford: Oxford University Press

Cooke, P., Clifton, N., and Oleaga, M. (2005) Social capital, firm embeddedness and regional development. Regional Studies 39 1065-1078

Dasgupta P (2003) Social capital and economic performance: Analytics. In: Serageldin I and Dasgupta P (eds) Social Capital: A Multifaceted Perspective. Washington, DC: World Bank, pp. 238-257.

Dasgupta P (2005) The economics of social capital. Economic Record 81(s1): S2-S21

Davidsson, P. and Honig, B. (2003) The role of social and human capital among nascent entrepreneurs. Journal of Business Venturing 18(3) 301-331.

De Carolis, D. and Saparito, P. (2006) Social capital, cognition and entrepreneurial opportunities: A theoretical framework. Entrepreneurship: Theory and Practice 30 41-56

Department for Communities and Local Government (2007) The English Indices of Deprivation (HMSO, London)

Dodd, S.D. (2002) Metaphors and meaning: a grounded cultural model of US entrepreneurship. Journal of Business Venturing 17 519-535

Evans, M. and Syrett, S. (2007) Generating social capital? The social economy and local economic development. European Urban and Regional Studies, 14(1), 55-74

Evans, M., North, D., Syrett, S., Sanderson, I. and Williams, C.C. (2006) The Economies of Deprived Neighbourhoods: Summary of Research (Department of Communities and Local Government, HMSO, London)

Fountain, J.E. (1998) Social capital: Its relationship to innovation in science and technology. Science and Public Policy, 25(2): 103-116

Frankish, J.S., Roberts, R.G., Coad, A. and Storey, D.J. (2014) Is entrepreneurship a route out of deprivation? Regional Studies 48(6) 1090-1107.

Fraser, S., Storey, D.J., Westhead, P. (2006) Student work placements in small firms: do they pay-off or shift tastes? Small Business Economics 26 125-144

Fukuyama, F. (2003) Social Capital and Civil Society. Washington, DC: International Monetary Fund

Gedajlovic, E., Honig, B., Moore, C.B., Payne, G.T. and Wright, M. (2013) Social capital and entrepreneurship: A schema and research agenda. Entrepreneurship and Theory and Practice 37 455-478

Granovetter, M. (1973) The Strength of Weak Ties. American Journal of Sociology 781360 1380

Granovetter, M. (1983) The Strength of Weak Ties: a network theory revisited. Sociological Theory 1 201-233

Granovetter, M. (1985) Economic Action and Social Structure: The Problem of Embeddedness. American Journal of Sociology 91 481-510

Greve, A. and Salaff J.W. (2003) Social networks and entrepreneurship" Entrepreneurship Theory and Practice 28(1) 1-22.

Hays, R.A. and Kogl, A.M. (2007) Neighborhood Attachment, Social Capital Building, and Political Participation: A Case Study of Low- and Moderate-Income Residents of Waterloo, Iowa. Journal of Urban Affairs 29 181-205

Higgins, P., Campanera, J. and Nobajas, A. (2012) Quality of life and spatial inequality in London. European Urban and Regional Studies, 21(1) 42-59

HM Treasury (2005) Enterprise and economic opportunity in deprived areas: a consultation on proposals for a Local Enterprise Growth Initiative (HM Stationary Office, London)

Hoang, H. and Antoncic, B. (2003) Network-based research in entrepreneurship: a critical review. Journal of Business Venturing 18 165-187 
Hogget, P. (1997) Contested Communities: Experiences, Struggles and Policies (Policy Press, Bristol)

Huggins R. and Williams N. (2009) Enterprise and public policy: a review of Labour government intervention in the United Kingdom" Environment and Planning C: Government and Policy 27 19-41

Huggins, R. and Williams, N. (2011) Entrepreneurship and Regional Competitiveness: The Role and Progression of Policy. Entrepreneurship and Regional Development, 23(9/10), 907-932

Jack SL, 2005, "The role, use and activation of strong and weak ties: A qualitative analysis" Journal of Management Studies 42 1233-1259

Kim, G. (2007) The analysis of self-employment levels over the life-cycle. Quarterly Review of Economics and Finance 47 397-410

King, G. and Zeng, L. (2001a) Explaining rare events in international relations. International Organization 55 693-715

King, G. and Zeng, L. (2001b) Logistic regression in rare events data. Political Analysis 9 $137-163$

Kisfalvi, V. (2002) The entrepreneur's character, life issues, and strategy making: A field study. Journal of Business Venturing 17 489-518

Kitchen, R. and Tate, N. (2001) Conducting Research in Human Geography: Theory, Practice and Methodology (Prentice Hall, London)

Knack, S. and Keefer, P. (1997) Does social capital have an economic payoff? A crosscountry investigation. Quarterly Journal of Economics 112 1251-1288

Kreiser, P.M., Patel, P.C. and Fiet, J.O. (2013) The Influence of Changes in Social Capital on Firm-Founding Activities. Entrepreneurship Theory and Practice 37 539-568

Lee, N. and Drever, E. (2014) Do SMEs in deprived areas find it harder to access finance? Evidence from the UK Small Business Survey. Entrepreneurship and Regional Development 26(3/4) 337-356.

Lee, R., Tuselmann, H., Jayarwana, D., and Rouse, J. (2011) Investigating the social capital and resource acquisition of entrepreneurs residing in deprived areas of England. Environment and Planning C: Government and Policy 29 1054-1072

Leeds City Council (2009) Regeneration through enterprise is working. Leeds City Council, Leeds

Leeds City Council (2011) Leeds 2030: Our vision to be the best city in the UK (Leeds Initiative, Leeds) Available at: http://www.leeds.gov.uk/docs/Vision\%20for\%20Leeds\%202011\%20-\%202030.pdf

Leeds City Council (2012) Inequality to inclusion (Leeds City Council, Leeds) Available at: http://www.leeds.gov.uk/docs/LEH\%2007\%20Inequality\%20to\%20inclusion.pdf

Levent, T.B., Masurel, E. and Nijkamp, P. (2003) Diversity in entrepreneurship: ethnic and female roles in urban economic life. International Journal of Social Economics 30(11) 1131-1161.

Lorenzen, M. (2007) Social capital and localised learning: proximity and place in technological and institutional dynamics. Urban Studies 44 799-817

Ma, Z. (2002) Social-capital mobilization and income returns to entrepreneurship: the case of return migration in rural China. Environment and Planning A. 34, 1763-1784

Malecki, E.J. (2012) Regional social capital: Why it matters. Regional Studies, 46, 1023 1039.

Maurer, I. and Ebers, M. (2006) Dynamics of social capital and their performance implications: lessons from biotechnology start-ups. Administrative Science Quarterly 51 262-292 
Middleton, A., Murie, A. and Groves, R. (2005) Social capital and neighbourhoods that work. Urban Studies 42 1711-1738

Miles, N. and Tully, J. (2007) Regional Development Agency Policy to Tackle Economic Exclusion? The Role of Social Capital in Distressed Communities. Regional Studies 41 855-866

Minniti, M., Bygrave, W.D. and Autio E. (2006) Global Entrepreneurship Monitor 2005 Executive Report (Babson College/London Business School: London)

Morgan, K. (2004) The exaggerated death of geography: learning, proximity and territorial innovation systems, Journal of Economic Geography 4, 3-21

Mueller, S.L. and CONWAY DATO-ON, M. (2013) A cross cultural study of gender-role orientation and entrepreneurial self-efficacy. International Entrepreneurship and Management Journal 9(1) 1-20

Okoli C. and Oh, W (2007) Investigating recognition-based performance in an open content community: a social capital perspective' Information and Management 44, 240-252

Organisation for Economic Co-operation and Development (2003) Entrepreneurship and Local Economic Development: Programme and Policy Recommendations (OECD, Paris)

Ostrom E and Ahn TK (eds) (2003) Foundations of Social Capital. Cheltenham: Edward Elgar

Parra-Requena, G., Molina-Morales, F.X., Garcia-Villaverde, P.M. (2010) The mediating effect of cognitive social capital on knowledge acquisition in clustered firms. Growth and Change, 41(1), 59-84.

Peck, J. (2016) Economic rationality meets celebrity urbanology: Exploring Edward Glaeser's city. International Journal of Urban and Regional Research, online first, DOI: $10.1111 / 1468-2427.12321$

Pitt, M. (1998) A tale of two gladiators: 'reading' entrepreneurs as texts. Organisational Studies 19 387-414

Portes, A. and Landolt, P. (1996) The Downside of Social Capital. The American Prospect 26 $18-21$

Portes, A. and Landolt, P. (2000) Social capital: promise and pitfalls of its role in development. Journal of Latin American Studies 32 529-547

Putnam, R. (1995) Bowling alone: America's declining social capital. Journal of Democracy $665-78$

Putnam, R.D. (2000) Bowling Alone: The Collapse and Revival of American Community (Simon \& Schuster, New York)

Ram, M., Barrett, G. and Jones, T. (2006) Ethnicity and entrepreneurship, In S Carter and D Jones-Evans (eds) Enterprise and Small Business, Principles, Policy and Practice, 2nd edition, pp.192-208.

Ram, M., Sanghera, B., Abbas, T., Barlow, G. and Jones, T. (2000) Ethnic minority business in comparative perspective: the case of the independent restaurant sector" Journal of Ethnic and Migration Studies 26(3) 495-510.

Reynolds, P.D., Bosma, N., Autio, E., Hunt, S., De Bono, D., Servais, I., Lopez-Garcia, L. and Chin, N. (2005) Global Entrepreneurship Monitor: data collection design and implementation 1998-2003. Small Business Economics 24(3) 205-231.

Robson, P.B. and Sexton, E.A. (1994) The effect of education and experience on selfemployment success. Journal of Business Venturing 9(2), 141-156.

Rouse, J. and Jayarwana, D. (2006) The financing of disadvantaged entrepreneurs: Are enterprise programmes overcoming the finance gap? International Journal of Entrepreneurial Behaviour and Research 12 388-400

Saparito, P.A. and Coombs, J.E. (2013) Bureaucratic systems' facilitating and hindering influence on social capital. Entrepreneurship and Theory and Practice 37 625-639 
Schneider, G., Plumper, T. and Baumann, S. (2000) Bringing Putnam to the European Regions: On the relevance of social capital for economic growth. European Urban and Regional Studies, 7(4), 307-317

Sequeira, J., Mueller, S.L. and McGee, J.E. (2007) The influence of social ties and selfefficacy in forming entrepreneurial intentions and motivating nascent behavior. Journal of Developmental Entrepreneurship 12(3), 275-293.

Slack, J. (2005) The New Entrepreneur Scholarships: self-employment as a means to tackle social deprivation. Education and Training 47 447-455

Sleutjes, B., Van Oort, F. and Schutjens, V. (2012) A place for area-based policy? The survival and growth of local firms in Dutch residential neighbourhoods. Journal of Urban Affairs 34(5): 533-558.

Sleutjes, B. and Schutjens, V. (2013) Anchoring of firms in the neighbourhood: Does local social and physical order affect local firms' investment strategies? European Planning Studies, 21(8): 1256-1275.

Sobel J (2002) Can we trust social capital? Journal of Economic Literature, 40(1): 139-154

Stephens, H.M. and Partridge, M.D. (2011) Do entrepreneurs enhance economic growth in lagging regions? Growth and Change, 42(4), 431-465.

Storey, D.J. and Johnson, S. (1987) Regional variations in entrepreneurship in the UK. Scottish Journal of Political Economy 34(2) 161-173

Sullivan, D.M. and Ford, C.M. (2014) How entrepreneurs use networks to address changing resource requirements during early venture development. Entrepreneurship Theory and Practice 38 551-574

Syrett, S. and Sepulveda, L. (2012) Urban governance and economic development in the diverse city. European Urban and Regional Studies, 19(3), 238-253

Thompson, P. Jones-Evans, D. and Kwong, C. (2010) Education and entrepreneurial activity: a comparison of White and South Asian men. International Small Business Journal, 28(2), 147-162

Thompson, P. Jones-Evans, D. and Kwong, C. (2012) Entrepreneurship in deprived urban communities: the case of Wales. Entrepreneurship Research Journal 2 1-33

Tiwana, A. (2008) Do bridging ties complement strong ties? An empirical examination of alliance ambidexterity. Strategic Management Journal 29 251-272

Van Auken, H., Fry, FL. and Stephens P. (2006) The influence of role models on entrepreneurial intentions. Journal of Developmental Entrepreneurship 11(2) 157-167.

Van Den Berg L., Pol, P.M.J. and Van Winden, W. (2004) Area-based policies and entrepreneurship: European initiatives, in OECD, Entrepreneurship: A Catalyst for Urban Regeneration, Paris: OECD, pp. 231-259.

Van Der Sluis, J., Van Praag, M. and Vijverberg, W. (2008) Education and entrepreneurship selection and performance: a review of the empirical literature. Journal of Economic Surveys 22(5) 795-841

Welter, F., Trettin, L. and Neumann, U. (2008) Fostering Entrepreneurship in Distressed Urban Neighbourhoods. International Entrepreneurship and Management Journal 4 109-128

Western, J., Stimson, R., Baum, S. and Van Gellecum, Y. (2005) Measuring community strength and social capital, Regional Studies, 39:8, 1095-1109

Westlund, H. (2011) Multidimensional entrepreneurship: Theoretical considerations and Swedish empirics. Regional Science Policy \& Practice, 3(3) 199-218.

Westlund, H. and Bolton R. (2003) Local social capital and entrepreneurship. Small Business Economics 21 77-133

Westlund, H., Larsson, J.P. and Olsson, A.R. (2014) Start-ups and Local Entrepreneurial Social Capital in the Municipalities of Sweden. Regional Studies, 48:6, 974-994 
Williams, N. and Williams, C. C. (2011) Tackling barriers to entrepreneurship in a deprived urban neighbourhood. Local Economy, 26(1), pp. 30-42

Williams, N. and Williams, C.C. (2012) Evaluating the socio-spatial contingency of entrepreneurial motivations: a case study of English deprived urban neighbourhoods. Entrepreneurship and Regional Development, 24(7/8), 661-684.

Woolcock M and Narayan D (2000) Social capital: Implications for development theory, research, and policy. World Bank Research Observer 15(2): 225-250 
Percentage reporting each number of sources of tie

\begin{tabular}{lcccccc} 
& & & & & & 3 \\
& Mean & \\
& s.d. & 0 & 1 & 2 & more \\
\hline Total Different Types of Tie & 0.738 & 0.868 & $48.8 \%$ & $34.4 \%$ & $11.9 \%$ & $4.9 \%$ \\
Total Different Strong Ties & 0.325 & 0.567 & $72.6 \%$ & $22.3 \%$ & $5.1 \%$ & $0.0 \%$ \\
Total Different Weak Ties & 0.408 & 0.637 & $66.0 \%$ & $28.5 \%$ & $4.2 \%$ & $1.3 \%$ \\
\hline
\end{tabular}

Table 2: Sources of advice that respondents would use if starting a business

Panel A - Engagement with Entrepreneurial Activities

\begin{tabular}{|c|c|c|c|c|c|c|}
\hline Source of Advice & $\begin{array}{c}\text { No } \\
\text { Entrepreneurial } \\
\text { Activity }\end{array}$ & $\begin{array}{c}\text { Entrepreneurial } \\
\text { Activity }\end{array}$ & All & $\chi^{2}$ & d.f. & p-value \\
\hline Friends and Family & $23.3 \%$ & $34.3 \%$ & $24.2 \%$ & 2.104 & {$[1]$} & $(0.147)$ \\
\hline Bank & $19.7 \%$ & $8.6 \%$ & $18.8 \%$ & & $\mathrm{n} / \mathrm{a}$ & \\
\hline Colleagues & $8.1 \%$ & $11.4 \%$ & $8.4 \%$ & & $\mathrm{n} / \mathrm{a}$ & \\
\hline Business Advisor & $6.6 \%$ & $17.1 \%$ & $7.5 \%$ & & $\mathrm{n} / \mathrm{a}$ & \\
\hline $\begin{array}{l}\text { College or } \\
\text { university }\end{array}$ & $3.4 \%$ & $5.7 \%$ & $3.6 \%$ & & $\mathrm{n} / \mathrm{a}$ & \\
\hline $\begin{array}{l}\text { Business advice } \\
\text { centre }\end{array}$ & $2.7 \%$ & $8.6 \%$ & $3.2 \%$ & & $\mathrm{n} / \mathrm{a}$ & \\
\hline $\begin{array}{l}\text { Chamber of } \\
\text { Commerce }\end{array}$ & $2.7 \%$ & $2.9 \%$ & $2.7 \%$ & & $\mathrm{n} / \mathrm{a}$ & \\
\hline Accountant & $2.0 \%$ & $2.9 \%$ & $2.0 \%$ & & $\mathrm{n} / \mathrm{a}$ & \\
\hline Financial Advisor & $1.2 \%$ & $2.9 \%$ & $1.4 \%$ & & $\mathrm{n} / \mathrm{a}$ & \\
\hline $\begin{array}{l}\text { Courses or } \\
\text { conferences }\end{array}$ & $0.7 \%$ & $5.7 \%$ & $1.1 \%$ & & $\mathrm{n} / \mathrm{a}$ & \\
\hline Solicitor & $1.0 \%$ & $0.0 \%$ & $0.9 \%$ & & $\mathrm{n} / \mathrm{a}$ & \\
\hline
\end{tabular}

Panel B Consideration of Entrepreneurial Activities

No

Consideration Consideration

of of

Entrepreneurial Entrepreneurial

\begin{tabular}{|c|c|c|c|c|c|c|}
\hline Source of Advice & Career & Career & All & $\chi^{2}$ & d.f. & p-value \\
\hline Friends and Family & $25.1 \%$ & $22.5 \%$ & $24.3 \%$ & 0.251 & {$[1]$} & $(0.616)$ \\
\hline Bank & $20.7 \%$ & $19.6 \%$ & $20.4 \%$ & 0.052 & {$[1]$} & $(0.819)$ \\
\hline Colleagues & $7.9 \%$ & $14.7 \%$ & $10.0 \%$ & 3.581 & {$[1]$} & $(0.058)$ \\
\hline Business Advisor & $7.5 \%$ & $5.9 \%$ & $7.0 \%$ & 0.279 & {$[1]$} & $(0.597)$ \\
\hline $\begin{array}{l}\text { College or } \\
\text { university }\end{array}$ & $1.3 \%$ & $7.8 \%$ & $3.3 \%$ & & $\mathrm{n} / \mathrm{a}$ & \\
\hline Business advice & $3.1 \%$ & $2.9 \%$ & $3.0 \%$ & & $\mathrm{n} / \mathrm{a}$ & \\
\hline
\end{tabular}


Chamber of

Commerce

$3.1 \%$

$3.9 \%$

$3.3 \%$

$\mathrm{n} / \mathrm{a}$

Accountant

$2.6 \%$

$2.0 \%$

$2.4 \%$

$\mathrm{n} / \mathrm{a}$

Financial Advisor

$1.8 \%$

$1.0 \%$

$1.5 \%$

$\mathrm{n} / \mathrm{a}$

Courses or

conferences

$0.9 \%$

$1.0 \%$

$0.9 \%$

$\mathrm{n} / \mathrm{a}$

Solicitor

$1.8 \%$

$0.0 \%$

$1.2 \%$

$\mathrm{n} / \mathrm{a}$ 
Table 3 - Spearman rank correlations of entrepreneurial activity and interest variables with control variables

\begin{tabular}{|c|c|c|c|c|c|c|c|c|c|c|c|}
\hline & $\begin{array}{c}1 . \\
\text { Entrepreneurially } \\
\text { Active }\end{array}$ & $\begin{array}{c}2 . \\
\text { Considered } \\
\text { or intending } \\
\text { to starting a } \\
\text { business } \\
\end{array}$ & 3 & 4 & 5 & 6 & 7 & 8 & 9 & 10 & 11 \\
\hline 3. Variety of Network Ties & $\begin{array}{c}0.090 \\
(0.059)\end{array}$ & $\begin{array}{c}0.027 \\
(0.589)\end{array}$ & & & & & & & & & \\
\hline 4. Variety of Strong Network Ties & $\begin{array}{c}0.078 \\
(0.101)\end{array}$ & $\begin{array}{c}0.020 \\
(0.683)\end{array}$ & $\begin{array}{c}0.672 \\
(0.000)\end{array}$ & & & & & & & & \\
\hline 5. Variety of Weak Network Ties & $\begin{array}{c}0.041 \\
(0.390)\end{array}$ & $\begin{array}{l}-0.004 \\
(0.931)\end{array}$ & $\begin{array}{c}0.734 \\
(0.000)\end{array}$ & $\begin{array}{c}0.046 \\
(0.333)\end{array}$ & & & & & & & \\
\hline $\begin{array}{l}\text { 6. Perceptions of area being poor } \\
\text { for business starts }\end{array}$ & $\begin{array}{l}-0.015 \\
(0.761)\end{array}$ & $\begin{array}{c}0.037 \\
(0.451)\end{array}$ & $\begin{array}{c}0.054 \\
(0.254)\end{array}$ & $\begin{array}{l}-0.024 \\
(0.610)\end{array}$ & $\begin{array}{c}0.103 \\
(0.030)\end{array}$ & & & & & & \\
\hline 7. Male & $\begin{array}{c}0.132 \\
(0.005)\end{array}$ & $\begin{array}{c}0.113 \\
(0.023)\end{array}$ & $\begin{array}{c}0.075 \\
(0.110)\end{array}$ & $\begin{array}{c}0.140 \\
(0.003)\end{array}$ & $\begin{array}{l}-0.027 \\
(0.559)\end{array}$ & $\begin{array}{c}0.021 \\
(0.661)\end{array}$ & & & & & \\
\hline 8. Age & $\begin{array}{c}0.030 \\
(0.535)\end{array}$ & $\begin{array}{l}-0.039 \\
(0.434)\end{array}$ & $\begin{array}{c}0.050 \\
(0.287)\end{array}$ & $\begin{array}{c}0.035 \\
(0.453)\end{array}$ & $\begin{array}{c}0.023 \\
(0.626)\end{array}$ & $\begin{array}{c}0.068 \\
(0.146)\end{array}$ & $\begin{array}{c}0.106 \\
(0.024)\end{array}$ & & & & \\
\hline 9. Non-White & $\begin{array}{c}0.011 \\
(0.819)\end{array}$ & $\begin{array}{c}0.063 \\
(0.206)\end{array}$ & $\begin{array}{c}0.010 \\
(0.833)\end{array}$ & $\begin{array}{c}0.033 \\
(0.487)\end{array}$ & $\begin{array}{c}0.016 \\
(0.742)\end{array}$ & $\begin{array}{l}-0.084 \\
(0.073)\end{array}$ & $\begin{array}{l}-0.010 \\
(0.836)\end{array}$ & $\begin{array}{l}-0.164 \\
(0.000)\end{array}$ & & & \\
\hline 10. Education & $\begin{array}{l}-0.079 \\
(0.096)\end{array}$ & $\begin{array}{l}-0.037 \\
(0.461)\end{array}$ & $\begin{array}{c}0.148 \\
(0.002)\end{array}$ & $\begin{array}{c}0.151 \\
(0.001)\end{array}$ & $\begin{array}{c}0.061 \\
(0.193)\end{array}$ & $\begin{array}{c}0.085 \\
(0.070)\end{array}$ & $\begin{array}{l}-0.052 \\
(0.267)\end{array}$ & $\begin{array}{l}-0.015 \\
(0.748)\end{array}$ & $\begin{array}{l}-0.053 \\
(0.258)\end{array}$ & & \\
\hline 11. Household Income ${ }^{a}$ & $\mathrm{n} / \mathrm{a}$ & $\begin{array}{c}0.116 \\
(0.036)\end{array}$ & $\begin{array}{c}0.180 \\
(0.001)\end{array}$ & $\begin{array}{c}0.152 \\
(0.006)\end{array}$ & $\begin{array}{c}0.102 \\
(0.063)\end{array}$ & $\begin{array}{c}-0.048 \\
(0.382)\end{array}$ & $\begin{array}{c}-0.132 \\
(0.016)\end{array}$ & $\begin{array}{c}0.210 \\
(0.000)\end{array}$ & $\begin{array}{l}-0.119 \\
(0.031)\end{array}$ & $\begin{array}{c}0.004 \\
(0.949)\end{array}$ & \\
\hline 12. Likelihood of moving & $\begin{array}{c}-0.024 \\
(0.621)\end{array}$ & $\begin{array}{c}0.110 \\
(0.026)\end{array}$ & $\begin{array}{c}0.026 \\
(0.584)\end{array}$ & $\begin{array}{l}-0.001 \\
(0.980)\end{array}$ & $\begin{array}{c}0.011 \\
(0.814)\end{array}$ & $\begin{array}{c}-0.058 \\
(0.219)\end{array}$ & $\begin{array}{c}0.032 \\
(0.500)\end{array}$ & $\begin{array}{l}-0.181 \\
(0.000)\end{array}$ & $\begin{array}{l}-0.005 \\
(0.910)\end{array}$ & $\begin{array}{c}0.004 \\
(0.928)\end{array}$ & $\begin{array}{l}-0.037 \\
(0.502)\end{array}$ \\
\hline
\end{tabular}

Notes: p-values in parentheses; (a) Figures relating to correlations are based on the subsample excluding those entrepreneurial active $(N=329)$ rather than the full sample $(N=442)$. 
Table 4 - Logit regressions of engagement with entrepreneurial activities, the influence of the variety of ties

\begin{tabular}{|c|c|c|c|}
\hline & Model 0a & Model 1a & Model 2a \\
\hline \multicolumn{4}{|l|}{ Would Seek Advice } \\
\hline Variety of Network Ties & & $\begin{array}{l}0.4403 \\
(0.026)\end{array}$ & $\begin{array}{l}0.3830 \\
(0.147)\end{array}$ \\
\hline $\begin{array}{l}\text { Variety of Network Ties * Poor Area to } \\
\text { Start a Business }\end{array}$ & & & $\begin{array}{l}0.1298 \\
(0.740)\end{array}$ \\
\hline \multicolumn{4}{|l|}{ Perceptions of Area for Business Starts } \\
\hline Poor Area to Start a Business & $\begin{array}{l}0.0009 \\
(0.998)\end{array}$ & $\begin{array}{l}-0.0208 \\
(0.956)\end{array}$ & $\begin{array}{l}-0.1439 \\
(0.786)\end{array}$ \\
\hline Male & $\begin{array}{l}1.2126 \\
(0.003)\end{array}$ & $\begin{array}{l}1.1897 \\
(0.004)\end{array}$ & $\begin{array}{l}1.1970 \\
(0.004)\end{array}$ \\
\hline \multicolumn{4}{|l|}{ Age (base category 25 to 44 years) } \\
\hline 16 to 19 years & $\begin{array}{r}-1.6115 \\
(0.131)\end{array}$ & $\begin{array}{c}-1.7998 \\
(0.096)\end{array}$ & $\begin{array}{r}-1.8132 \\
(0.094)\end{array}$ \\
\hline 20 to 24 years & $\begin{array}{r}-0.4455 \\
(0.366)\end{array}$ & $\begin{array}{l}-0.4342 \\
(0.383)\end{array}$ & $\begin{array}{l}-0.4304 \\
(0.387)\end{array}$ \\
\hline 45 to 59 years & $\begin{array}{l}-0.9988 \\
(0.082)\end{array}$ & $\begin{array}{l}-1.0708 \\
(0.065)\end{array}$ & $\begin{array}{l}-1.0699 \\
(0.065)\end{array}$ \\
\hline Non-White & $\begin{array}{l}0.1968 \\
(0.691)\end{array}$ & $\begin{array}{l}0.1273 \\
(0.800)\end{array}$ & $\begin{array}{l}0.1092 \\
(0.829)\end{array}$ \\
\hline \multicolumn{4}{|l|}{$\begin{array}{l}\text { Education (base category NVQ level } 1 \\
\text { or } 2 \text { ) }\end{array}$} \\
\hline No Formal Qualifications & $\begin{array}{l}0.8424 \\
(0.058)\end{array}$ & $\begin{array}{l}0.9672 \\
(0.034)\end{array}$ & $\begin{array}{l}0.9789 \\
(0.032)\end{array}$ \\
\hline NVQ level3 or higher & $\begin{array}{l}0.2558 \\
(0.668)\end{array}$ & $\begin{array}{l}0.1566 \\
(0.798)\end{array}$ & $\begin{array}{l}0.1680 \\
(0.783)\end{array}$ \\
\hline \multicolumn{4}{|l|}{$\begin{array}{l}\text { Likelihood of moving (base category } \\
\text { neither likely nor unlikely to move) }\end{array}$} \\
\hline Likely to move & $\begin{array}{r}-0.0292 \\
(0.958)\end{array}$ & $\begin{array}{l}0.0057 \\
(0.992)\end{array}$ & $\begin{array}{l}-0.0007 \\
(0.999)\end{array}$ \\
\hline Not likely to move & $\begin{array}{l}0.2127 \\
(0.678)\end{array}$ & $\begin{array}{l}0.2882 \\
(0.578)\end{array}$ & $\begin{array}{l}0.2961 \\
(0.568)\end{array}$ \\
\hline
\end{tabular}

Notes: p-values in parentheses 
Table 4: Continued

Model 0a

Model 1a

Model 2a

\begin{tabular}{|c|c|c|c|}
\hline $\begin{array}{l}\text { Area (base category Burmantofts and } \\
\text { Richmond Hill) }\end{array}$ & & & \\
\hline Fairfield & $\begin{array}{l}0.3962 \\
(0.523)\end{array}$ & $\begin{array}{l}0.4899 \\
(0.439)\end{array}$ & $\begin{array}{l}0.5010 \\
(0.429)\end{array}$ \\
\hline Little London & $\begin{array}{c}0.5271 \\
(0.368)\end{array}$ & $\begin{array}{l}0.5992 \\
(0.310)\end{array}$ & $\begin{array}{l}0.5759 \\
(0.333)\end{array}$ \\
\hline South Leeds & $\begin{array}{l}0.6362 \\
(0.269)\end{array}$ & $\begin{array}{l}0.7175 \\
(0.219)\end{array}$ & $\begin{array}{l}0.7097 \\
(0.225)\end{array}$ \\
\hline South Seacroft and Gipton & $\begin{array}{r}-0.4028 \\
(0.539)\end{array}$ & $\begin{array}{l}-0.2749 \\
(0.679)\end{array}$ & $\begin{array}{l}-0.2825 \\
(0.671)\end{array}$ \\
\hline Constant & $\begin{array}{r}-3.7655 \\
(0.000)\end{array}$ & $\begin{array}{l}-4.2581 \\
(0.000) \\
\end{array}$ & $\begin{array}{r}-4.2130 \\
(0.000)\end{array}$ \\
\hline$N$ & 442 & 442 & 442 \\
\hline $\begin{array}{l}\text { LR-test (null of constant probability) } \\
\text { d.f } \\
\text { p-value }\end{array}$ & $\begin{array}{c}22.02 \\
{[14]} \\
(0.078)\end{array}$ & $\begin{array}{c}26.75 \\
{[15]} \\
(0.031)\end{array}$ & $\begin{array}{c}26.86 \\
{[16]} \\
(0.043)\end{array}$ \\
\hline$R^{2}$ & 0.090 & 0.109 & 0.110 \\
\hline Hosmer-Lemeshow Test & $\begin{array}{c}6.51 \\
(0.590)\end{array}$ & $\begin{array}{c}3.64 \\
(0.888)\end{array}$ & $\begin{array}{c}3.6 \\
(0.891)\end{array}$ \\
\hline Percentage Correct & $92.1 \%$ & $92.1 \%$ & $92.1 \%$ \\
\hline AIC & 252.7 & 249.9 & 251.8 \\
\hline $\mathrm{SIC}$ & 314.0 & 315.4 & 321.4 \\
\hline $\begin{array}{l}\text { LR-test (joint insignificance of variety } \\
\text { of ties) } \\
\text { d.f } \\
\text { p-value }\end{array}$ & & $\begin{array}{c}4.74 \\
{[1]} \\
(0.030)\end{array}$ & $\begin{array}{c}4.85 \\
{[2]} \\
(0.089)\end{array}$ \\
\hline
\end{tabular}

Notes: $p$-values in parentheses 
Table 5 - Logit regressions of consideration of an entrepreneurial career, the influence of the variety of ties

\begin{tabular}{|c|c|c|c|}
\hline & Model Ob & Model 1b & Model 2b \\
\hline \multicolumn{4}{|l|}{ Would Seek Advice } \\
\hline Variety of Network Ties & & $\begin{array}{l}0.0505 \\
(0.729)\end{array}$ & $\begin{array}{l}-0.3211 \\
(0.147)\end{array}$ \\
\hline $\begin{array}{l}\text { Variety of Network Ties * Poor Area to } \\
\text { Start a Business }\end{array}$ & & & $\begin{array}{l}0.7080 \\
(0.018)\end{array}$ \\
\hline \multicolumn{4}{|l|}{ Perceptions of Area for Business Starts } \\
\hline Poor Area to Start a Business & $\begin{array}{l}0.1406 \\
(0.594)\end{array}$ & $\begin{array}{l}0.1323 \\
(0.618)\end{array}$ & $\begin{array}{l}-0.4099 \\
(0.242)\end{array}$ \\
\hline Male & $\begin{array}{l}0.7745 \\
(0.003)\end{array}$ & $\begin{array}{l}0.7729 \\
(0.003)\end{array}$ & $\begin{array}{l}0.8161 \\
(0.002)\end{array}$ \\
\hline \multicolumn{4}{|l|}{ Age (base category 25 to 44 years) } \\
\hline 16 to 19 years & $\begin{array}{r}-0.1917 \\
(0.698)\end{array}$ & $\begin{array}{r}-0.2043 \\
(0.681)\end{array}$ & $\begin{array}{r}-0.1785 \\
(0.722)\end{array}$ \\
\hline 20 to 24 years & $\begin{array}{r}-0.0095 \\
(0.977)\end{array}$ & $\begin{array}{r}-0.0085 \\
(0.980)\end{array}$ & $\begin{array}{c}0.0176 \\
(0.959)\end{array}$ \\
\hline 45 to 59 years & $\begin{array}{r}-0.2587 \\
(0.462)\end{array}$ & $\begin{array}{c}-0.2674 \\
(0.449)\end{array}$ & $\begin{array}{r}-0.2535 \\
(0.475)\end{array}$ \\
\hline Non-White & $\begin{array}{l}0.1754 \\
(0.612)\end{array}$ & $\begin{array}{l}0.1711 \\
(0.621)\end{array}$ & $\begin{array}{l}0.1084 \\
(0.758)\end{array}$ \\
\hline \multicolumn{4}{|l|}{$\begin{array}{l}\text { Education (base category NVQ level } 1 \\
\text { or 2) }\end{array}$} \\
\hline No Formal Qualifications & $\begin{array}{l}0.1544 \\
(0.599)\end{array}$ & $\begin{array}{l}0.1598 \\
(0.587)\end{array}$ & $\begin{array}{l}0.2097 \\
(0.483)\end{array}$ \\
\hline NVQ level3 or higher & $\begin{array}{l}0.0662 \\
(0.860)\end{array}$ & $\begin{array}{l}0.0509 \\
(0.893)\end{array}$ & $\begin{array}{l}0.1578 \\
(0.682)\end{array}$ \\
\hline \multicolumn{4}{|l|}{$\frac{\text { Household Income (base category }}{£ 10,000 \text { to } £ 19,999)}$} \\
\hline$£ 0$ to $£ 9999$ & $\begin{array}{l}0.0582 \\
(0.853)\end{array}$ & $\begin{array}{l}0.0662 \\
(0.834)\end{array}$ & $\begin{array}{l}0.0751 \\
(0.814)\end{array}$ \\
\hline$£ 20,000$ to $£ 29,999$ & $\begin{array}{r}-0.2643 \\
(0.559)\end{array}$ & $\begin{array}{r}-0.2775 \\
(0.542)\end{array}$ & $\begin{array}{c}-0.3124 \\
(0.501)\end{array}$ \\
\hline$£ 30,000$ or more & $\begin{array}{l}1.0397 \\
(0.005)\end{array}$ & $\begin{array}{l}1.0274 \\
(0.006)\end{array}$ & $\begin{array}{l}1.1113 \\
(0.003)\end{array}$ \\
\hline \multicolumn{4}{|l|}{$\begin{array}{l}\text { Likelihood of moving (base category } \\
\text { neither likely nor unlikely to move) }\end{array}$} \\
\hline Likely to move & $\begin{array}{l}0.3000 \\
(0.415)\end{array}$ & $\begin{array}{l}0.3144 \\
(0.396)\end{array}$ & $\begin{array}{c}0.3492 \\
(0.354)\end{array}$ \\
\hline Not likely to move & $\begin{array}{c}-0.3026 \\
(0.400)\end{array}$ & $\begin{array}{c}-0.2880 \\
(0.426)\end{array}$ & $\begin{array}{r}-0.2809 \\
(0.443)\end{array}$ \\
\hline
\end{tabular}

Notes: p-values in parentheses 
Table 5: Continued

Model 4

Model 5

Model 6

Area (base category Burmantofts and

Richmond Hill)

Fairfield

$-0.2940$

$-0.2845$

$-0.2114$

$(0.520)$

(0.534)

(0.648)

Little London

0.0801

0.0849

0.0493

(0.849)

(0.840)

(0.908)

South Leeds

0.2937

0.3018

0.2834

$(0.461)$

$(0.450)$

$(0.484)$

South Seacroft and Gipton

0.6211

0.6336

0.6404

(0.119)

(0.113)

(0.115)

\begin{tabular}{l} 
Constant \\
\hline$N$ \\
LR-test (null of constant probability) \\
d.f \\
p-value \\
$R^{2}$
\end{tabular}

Hosmer-Lemeshow Test

$$
-1.6692
$$

$-1.7176$

$-1.5686$

(0.001)

(0.001)

(0.003)

329

329

33.37
$[17]$

33.49

39.39

$(0.010)$

[18]

(0.015)

[19]

$(0.004)$

0.082

0.082

0.097
Percentage Correct
AIC
SIC
LR-test (joint insignificance of variety of ties)
d.f

7.38

11.54

11.55

$(0.496)$

(0.173)

(0.173)

$70.2 \%$

$69.9 \%$

$71.7 \%$

410.0

411.9

408.0

478.3

484.0

483.9

0.12

6.02

Notes: $p$-values in parentheses 
Table 6 - Logit regressions of engagement with entrepreneurial activities, the influence of the variety of ties by type

\begin{tabular}{|c|c|c|}
\hline & Model 3a & Model 4a \\
\hline \multicolumn{3}{|l|}{ Would Seek Advice } \\
\hline Variety of Strong Network Ties & $\begin{array}{l}0.4145 \\
(0.162)\end{array}$ & $\begin{array}{l}0.4100 \\
(0.286)\end{array}$ \\
\hline Variety of Weak Network Ties & $\begin{array}{l}0.4617 \\
(0.085)\end{array}$ & $\begin{array}{l}0.3563 \\
(0.364)\end{array}$ \\
\hline $\begin{array}{l}\text { Variety of Strong Network Ties * Poor Area to Start a } \\
\text { Business }\end{array}$ & & $\begin{array}{l}0.0285 \\
(0.962)\end{array}$ \\
\hline $\begin{array}{l}\text { Variety of Weak Network Ties * Poor Area to Start a } \\
\text { Business }\end{array}$ & & $\begin{array}{l}0.2035 \\
(0.705)\end{array}$ \\
\hline \multicolumn{3}{|l|}{ Perceptions of Area for Business Starts } \\
\hline Poor Area to Start a Business & $\begin{array}{r}-0.0231 \\
(0.951)\end{array}$ & $\begin{array}{l}-0.1380 \\
(0.795)\end{array}$ \\
\hline Male & $\begin{array}{l}1.1980 \\
(0.005)\end{array}$ & $\begin{array}{l}1.2067 \\
(0.004)\end{array}$ \\
\hline \multicolumn{3}{|l|}{ Age (base category 25 to 44 years) } \\
\hline 16 to 19 years & $\begin{array}{l}-1.8066 \\
(0.095)\end{array}$ & $\begin{array}{r}-1.8138 \\
(0.094)\end{array}$ \\
\hline 20 to 24 years & $\begin{array}{l}-0.4327 \\
(0.385)\end{array}$ & $\begin{array}{l}-0.4282 \\
(0.390)\end{array}$ \\
\hline 45 to 59 years & $\begin{array}{l}-1.0684 \\
(0.065)\end{array}$ & $\begin{array}{r}-1.0737 \\
(0.065)\end{array}$ \\
\hline Non-White & $\begin{array}{l}0.1244 \\
(0.805)\end{array}$ & $\begin{array}{l}0.0953 \\
(0.851)\end{array}$ \\
\hline \multicolumn{3}{|l|}{ Education (base category NVQ level 1 or 2 ) } \\
\hline No Formal Qualifications & $\begin{array}{l}0.9673 \\
(0.034)\end{array}$ & $\begin{array}{l}0.9780 \\
(0.033)\end{array}$ \\
\hline NVQ level3 or higher & $\begin{array}{l}0.1591 \\
(0.795)\end{array}$ & $\begin{array}{l}0.1702 \\
(0.781)\end{array}$ \\
\hline
\end{tabular}

Notes: p-values in parentheses 


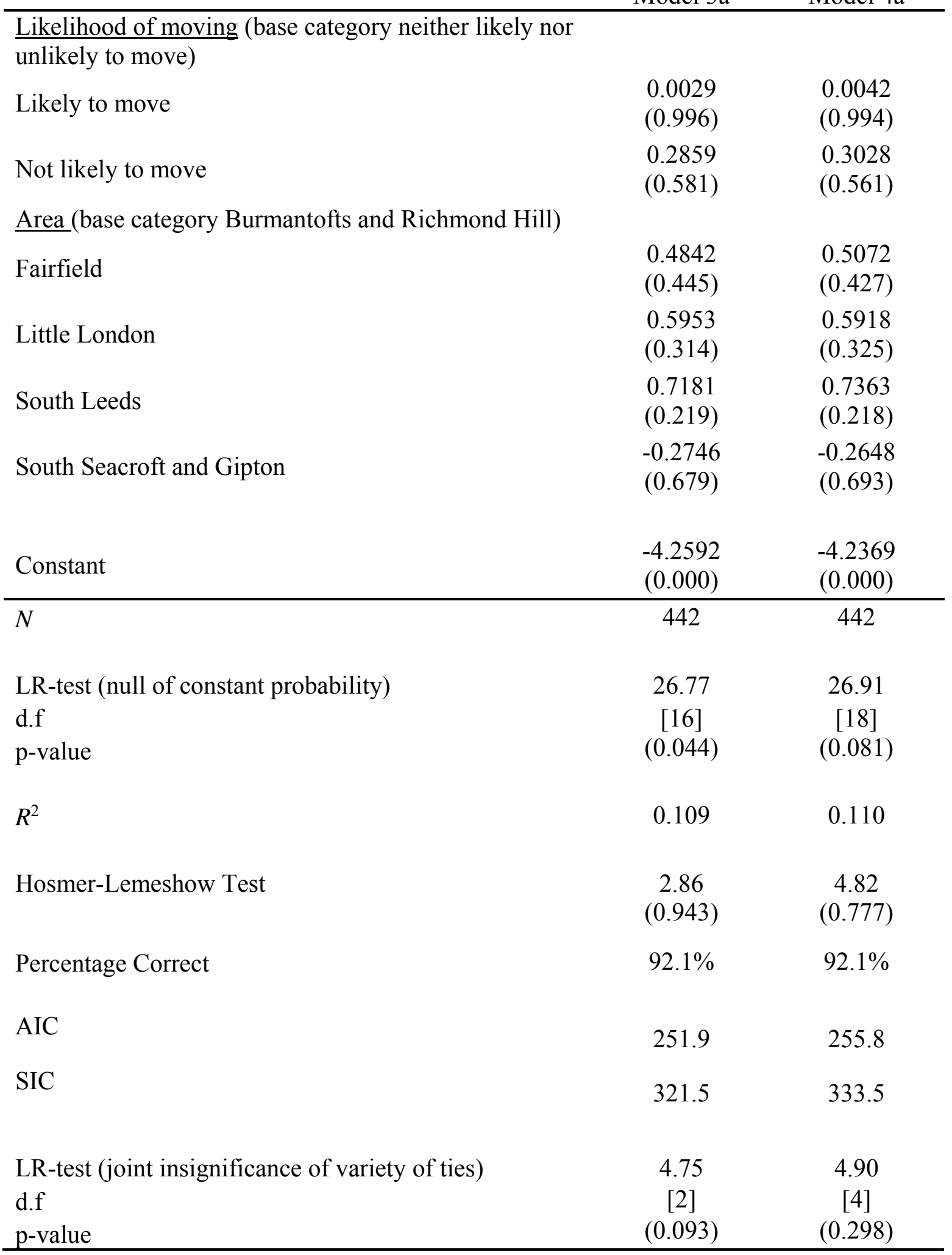

Notes: $p$-values in parentheses 
Table 7 - Logit regressions of consideration of an entrepreneurial career, the influence of the variety of ties by type

\begin{tabular}{|c|c|c|}
\hline & Model 3b & Model 4b \\
\hline \multicolumn{3}{|l|}{$\underline{\text { Would Seek Advice }}$} \\
\hline Variety of Strong Network Ties & $\begin{array}{r}-0.0135 \\
(0.951)\end{array}$ & $\begin{array}{r}-0.2594 \\
(0.399)\end{array}$ \\
\hline Variety of Weak Network Ties & $\begin{array}{l}0.1033 \\
(0.601)\end{array}$ & $\begin{array}{r}-0.3914 \\
(0.228)\end{array}$ \\
\hline $\begin{array}{l}\text { Variety of Strong Network Ties * Poor Area to Start a } \\
\text { Business }\end{array}$ & & $\begin{array}{l}0.5416 \\
(0.213)\end{array}$ \\
\hline $\begin{array}{l}\text { Variety of Weak Network Ties * Poor Area to Start a } \\
\text { Business }\end{array}$ & & $\begin{array}{l}0.8501 \\
(0.042)\end{array}$ \\
\hline \multicolumn{3}{|l|}{ Perceptions of Area for Business Starts } \\
\hline Poor Area to Start a Business & $\begin{array}{l}0.1274 \\
(0.631)\end{array}$ & $\begin{array}{r}-0.4075 \\
(0.245)\end{array}$ \\
\hline Male & $\begin{array}{l}0.7841 \\
(0.003)\end{array}$ & $\begin{array}{l}0.8303 \\
(0.002)\end{array}$ \\
\hline \multicolumn{3}{|l|}{ Age (base category 25 to 44 years) } \\
\hline 16 to 19 years & $\begin{array}{c}-0.2087 \\
(0.675)\end{array}$ & $\begin{array}{r}-0.1769 \\
(0.725)\end{array}$ \\
\hline 20 to 24 years & $\begin{array}{r}-0.0041 \\
(0.990)\end{array}$ & $\begin{array}{l}0.0164 \\
(0.962)\end{array}$ \\
\hline 45 to 59 years & $\begin{array}{r}-0.2681 \\
(0.448)\end{array}$ & $\begin{array}{r}-0.2595 \\
(0.465)\end{array}$ \\
\hline Non-White & $\begin{array}{l}0.1618 \\
(0.641)\end{array}$ & $\begin{array}{l}0.0995 \\
(0.778)\end{array}$ \\
\hline \multicolumn{3}{|l|}{ 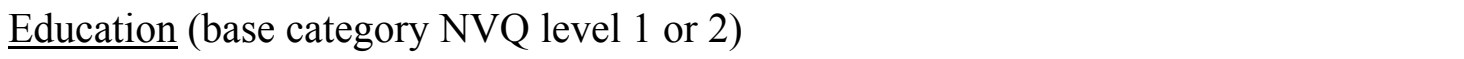 } \\
\hline No Formal Qualifications & $\begin{array}{l}0.1552 \\
(0.599)\end{array}$ & $\begin{array}{l}0.2079 \\
(0.487)\end{array}$ \\
\hline NVQ level3 or higher & $\begin{array}{l}0.0551 \\
(0.884)\end{array}$ & $\begin{array}{l}0.1663 \\
(0.665)\end{array}$ \\
\hline \multicolumn{3}{|l|}{ 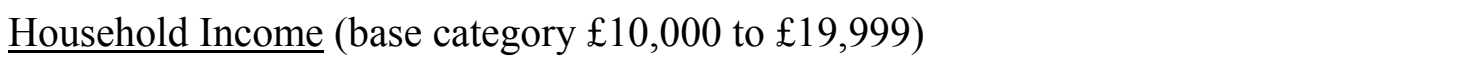 } \\
\hline$£ 0$ to $£ 9999$ & $\begin{array}{l}0.0641 \\
(0.839)\end{array}$ & $\begin{array}{l}0.0801 \\
(0.802)\end{array}$ \\
\hline$£ 20,000$ to $£ 29,999$ & $\begin{array}{r}-0.2778 \\
(0.541)\end{array}$ & $\begin{array}{r}-0.3087 \\
(0.506)\end{array}$ \\
\hline$£ 30,000$ or more & $\begin{array}{l}1.0406 \\
(0.005)\end{array}$ & $\begin{array}{l}1.1061 \\
(0.004)\end{array}$ \\
\hline
\end{tabular}

Notes: p-values in parentheses 


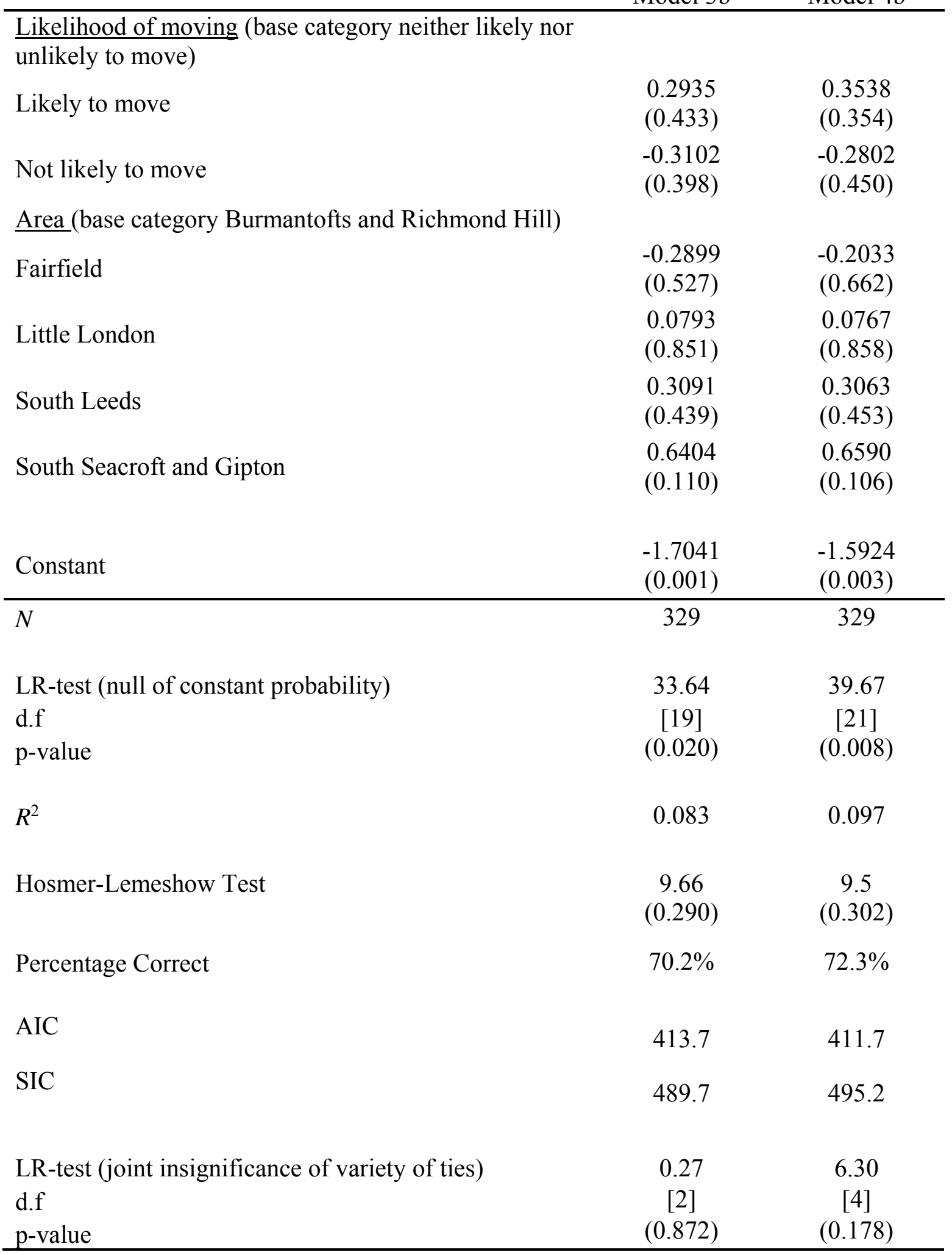

Notes: p-values in parentheses 
Table A1: Comparison of sample characteristics with census data

\begin{tabular}{|c|c|c|c|}
\hline Profile classification & $\begin{array}{c}\text { Number } \\
\text { of responses }\end{array}$ & $\begin{array}{l}\text { Percentage of } \\
\text { responses }\end{array}$ & Census data \\
\hline \multicolumn{4}{|l|}{ Gender } \\
\hline Male & 229 & $52 \%$ & $51 \%$ \\
\hline Female & 213 & $48 \%$ & $49 \%$ \\
\hline chi-square test & 0.12 & {$[1]$} & $(0.73)$ \\
\hline \multicolumn{4}{|l|}{ Age } \\
\hline$\overline{16-19}$ & 37 & $8 \%$ & $11 \%$ \\
\hline $20-24$ & 100 & $23 \%$ & $26 \%$ \\
\hline $25-44$ & 226 & $51 \%$ & $44 \%$ \\
\hline $45-59$ & 79 & $18 \%$ & $19 \%$ \\
\hline chi-square test & 10.59 & {$[3]$} & $(0.02)$ \\
\hline \multicolumn{4}{|l|}{ Ethnicity } \\
\hline White - British & 350 & $79 \%$ & $77 \%$ \\
\hline BME & 82 & $18 \%$ & $21 \%$ \\
\hline White - any other background & 10 & $2 \%$ & $2 \%$ \\
\hline chi-square test & 1.8 & {$[2]$} & $(0.43)$ \\
\hline \multicolumn{4}{|l|}{ Highest educational level } \\
\hline$\overline{\text { No qualifications }}$ & 198 & $45 \%$ & $49 \%$ \\
\hline Level 1 qualifications (equivalent to one & & & \\
\hline GCSE pass) & 53 & $12 \%$ & $10 \%$ \\
\hline $\begin{array}{l}\text { Level } 2 \text { qualifications (equivalent to } 5+ \\
\text { GCSE passes) }\end{array}$ & 39 & $9 \%$ & $9 \%$ \\
\hline $\begin{array}{l}\text { Level } 3 \text { qualifications (equivalent to } 2+ \\
\text { A-levels) }\end{array}$ & 65 & $15 \%$ & $16 \%$ \\
\hline $\begin{array}{l}\text { Level } 4 / 5 \text { qualifications (first } \\
\text { degree/higher degree) }\end{array}$ & 32 & $7 \%$ & $6 \%$ \\
\hline $\begin{array}{l}\text { Other qualifications (e.g. City \& Guilds, } \\
\text { BTEC, Edexcel) } \\
\text { chi-square test }\end{array}$ & $\begin{array}{l}55 \\
7.6\end{array}$ & $\begin{array}{c}12 \% \\
{[5]}\end{array}$ & $\begin{array}{l}10 \% \\
(0.18)\end{array}$ \\
\hline
\end{tabular}

Notes: p-values in parentheses; degrees of freedom in squared brackets 
Table A2: Distribution of respondent and area characteristics

\begin{tabular}{|c|c|c|}
\hline & & Sample \\
\hline Suitability of Area for Business Start & Poor Place to Start Business & $48.2 \%$ \\
\hline Gender & Male & $51.8 \%$ \\
\hline Age & $\begin{array}{c}16-19 \text { years } \\
20-24 \text { years } \\
25-44 \text { years* } \\
45-59 \text { years }\end{array}$ & $\begin{array}{c}8.4 \% \\
22.6 \% \\
51.1 \% \\
17.9 \%\end{array}$ \\
\hline Ethnic Background & Minority & $18.6 \%$ \\
\hline $\begin{array}{c}\text { Educational Attainment (Highest level } \\
\text { of qualifications) }\end{array}$ & $\begin{array}{c}\text { No Formal } \\
\text { Level } 1 \text { and } 2 \text { NVQ* } \\
\text { Level } 3+\text { NVQ }\end{array}$ & $\begin{array}{l}44.8 \% \\
33.3 \% \\
21.9 \%\end{array}$ \\
\hline Household Income $^{\mathrm{a}}$ & $\begin{array}{c}<£ 10,000 \\
£ 10,000 \text { to } £ 19,999^{*} \\
£ 20,000 \text { to } £ 29,999 \\
£ 30,000 \text { or more }\end{array}$ & $\begin{array}{c}29.5 \% \\
27.5 \% \\
9.8 \% \\
14.0 \%\end{array}$ \\
\hline Likelihood of Moving & $\begin{array}{l}\text { Likely to move } \\
\text { Not sure* } \\
\text { Unlikely to move }\end{array}$ & $\begin{array}{l}34.4 \% \\
18.3 \% \\
47.3 \%\end{array}$ \\
\hline Area & $\begin{array}{c}\text { Burmantofts and Richmond Hill* } \\
\text { Fairfield } \\
\text { Little London } \\
\text { South Leeds } \\
\text { South Seacroft and Gipton }\end{array}$ & $\begin{array}{l}22.6 \% \\
17.9 \% \\
19.0 \% \\
20.1 \% \\
20.4 \%\end{array}$ \\
\hline$N$ & & 442 \\
\hline
\end{tabular}

Notes: (a) $N=329$ for Household Income as only used in considering entrepreneurship regressions; * represents the base category omitted in the regressions 